\title{
Patrimonio 2.0: bombardeo en las redes
}

\author{
Sandra Gracia Melero | Equipo Arte urbano y público, GE-IIC
}

URL de la contribución <www.iaph.es/revistaph/index.php/revistaph/article/view/4923>

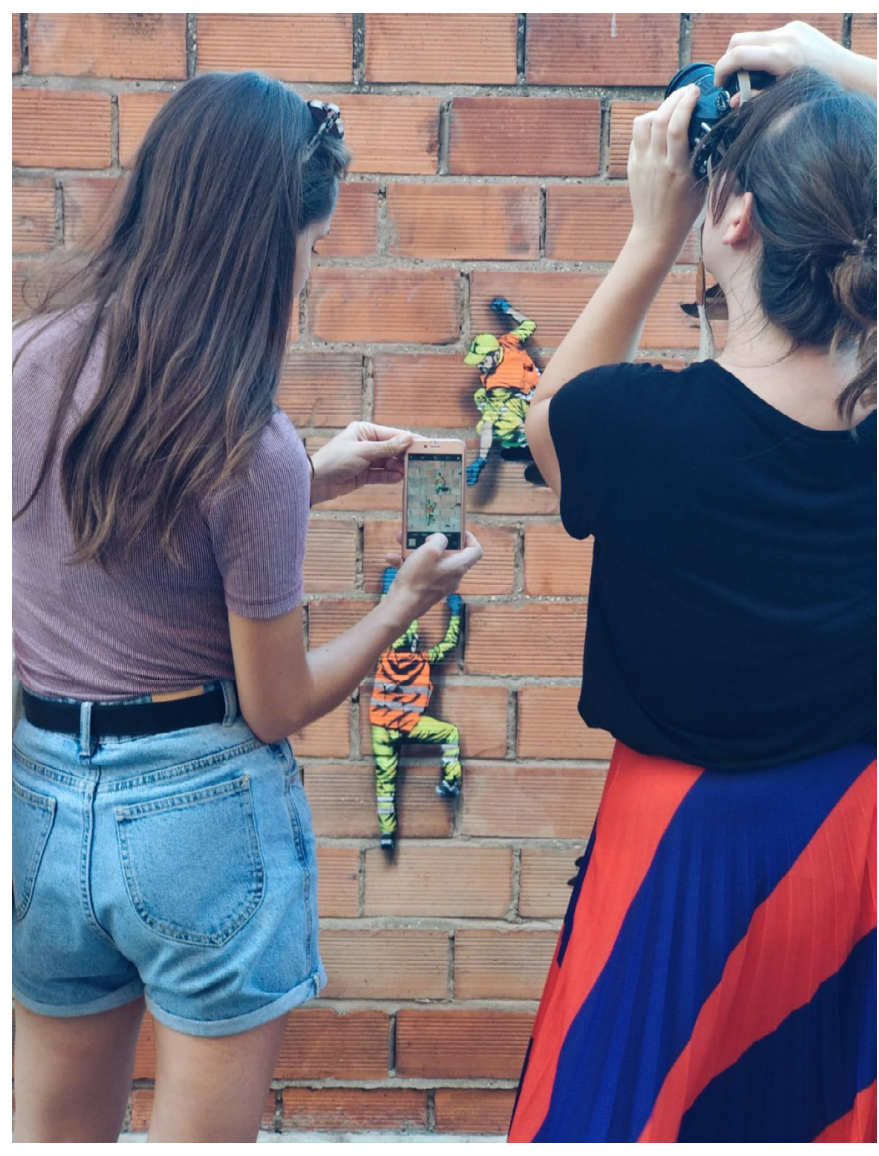

Resulta fundamental la labor de profesionales del patrimonio que estudien, evalúen, conserven y pongan en valor las creaciones de arte urbano

La hegemonía de los medios digitales y el uso de las redes sociales ha trasladado el acto de contemplación de las manifestaciones y obras realizadas en la calle -y el debate que generan- desde el espacio público al espacio virtual.

Hoy por hoy se hace difícil comprender el proceso creativo, la repercusión y el interés de salvaguarda de muchas de estas manifestaciones sin tener en cuenta los nuevos medios y lenguajes tecnológicos.

El arte urbano y el muralismo contemporáneo de las calles bombardean ahora las redes sociales, de tal forma que se ha convertido en uno de los principales fines de su creación. Ahora más que nunca, el arte de la calle parece prescindir de la importancia de la materia y de su perdurabilidad física. Para muchos creadores (y espectadores) basta con una imagen que registre el acto y que quede para la posteridad; una suerte de fetiche digital que pueda viralizarse y viajar por el globo. La consecuencia de esto es evidente: existe una pérdida de la experiencia que implica contemplar y vivir estas manifestaciones en el contexto en el que fueron creadas. Se ha dejado de recorrer las calles; ahora son un mero lugar de tránsito y no de encuentro (Abarca 2011), algo que inevitablemente se ha visto agravado por la actual pandemia. La experiencia de contemplación in situ es difícilmente transmitible a través de un post. Esto hace que los artistas, adentrados en la vorágine de los festivales de arte urbano y de los murales comisionados, lleven a cabo proyectos que, en ocasiones, dejan de nacer del estudio del entorno y el espacio urbano para basarse únicamente en visibilizar su discurso personal y desarrollar una reconocible estética o marca. ¿Han pasado los festivales a valorar por encima del discurso el número de visibilizaciones y de likes?

Pese a esta sobrestimulación y uso indiscriminado, las tecnologías de la información y la comunicación (TIC) ofrecen a los grafiteros y a los artistas urbanos nuevos recursos con los que trasmitir y sobre los que reflexionar en torno a sus piezas u obras. En el caso de la cultura del grafiti, resulta especialmente interesante la aparición de perfiles de Instagram donde se documentan las acciones, el deambular de las calles y el descubrimiento 
del "tercer paisaje"1. No es tanto el registro de la pieza en sí, sino documentar el proceso para competir en riesgo contra sus iguales de la escena. Cuentas como la de @les_forces_du_desordre_en Instagram suponen una valiosa fuente de información sobre corrientes como la urban exploration (colarse en túneles o espacios industriales en desuso) o el rooftopping (escalar edificios con pocos medios inmortalizándolo con una fotografía). Este tipo de documentación se hace mucho más accesible ahora, ya que antes era más común encontrarla únicamente en medios como fanzines de corta tirada.

Por otro lado, en el ámbito del arte urbano existen artistas que reflexionan sobre la trasmisión de sus obras a través de los social media y de la influencia de las TIC en la sociedad. Un ejemplo de ello es Ampparito, que trabaja en obras ligadas al contexto y a la ciudad pero relacionándolas con cómo su percepción y lectura cambia tras ser compartidas de manera digital.

Otra alternativa dentro del empleo de estas redes es la que realiza el artista Gonzalo Borondo, haciendo uso de las mismas a modo de archivo o portfolio de sus obras, con una estética cuidada y meditada, alejándose por tanto del fast art que se extiende por la red.

Muchos de estos artistas han dado el salto a las galerías, las ferias de arte o incluso a los museos, pero parte de su producción artística previa sigue en las calles o en la web, con el riesgo de pérdida que ello supone. Se puede afirmar, por tanto, que existe un Patrimonio 2.0 que precisa ser catalogado y archivado, siendo en ocasiones uno de los últimos vestigios de obras y manifestaciones que ya se han diluido o han desaparecido de las calles. Ante tanto ruido visual se hace indiscutiblemente necesaria la labor de profesionales del patrimonio que estudien, evalúen, seleccionen, conserven y pongan en valor dichas creaciones, en pos de crear un ideario del devenir de nuestros paisajes urbanos.

Además de recurrir a estas redes virtuales de una forma pasiva, se pueden emplear y diseñar nuevos medios tecnológicos que ayuden a llevar un registro de las obras, a hacer seguimiento de su estado de conservación y a conseguir el feedback de la ciudadanía, entre otras muchas posibilidades. El impulso del empleo de aplicaciones móviles, de códigos QR o de tecnologías de realidad aumentada (Gayo y Gracia 2018), diseñadas y gestionadas por profesionales del patrimonio, devolverían al arte urbano y al muralismo contemporáneo esa relación con el medio y ese carácter colaborativo que quizás se haya perdido por el exceso de las redes sociales y el consumo compulsivo de imágenes en red.

\section{NOTAS}

1. Término acuñado por Gilles Clément para referirse a aquellos espacios o lugares abandonados o no vividos por los hombres como los márgenes de las carreteras, las arquitecturas abandonadas, la parte inferior de los puentes, etc. (Clément 2007).

\section{BIBLIOGRAFÍA}

- Abarca, J. (2011) Lo público y el arte. Urbanario, 13 de abril de 2011. Disponible en: https://urbanario.es/articulo/lo-publicoy-el-arte/?portfolioCats $=12 \% 2$ C10\%2C124\%2C9\%2C123\%2 C7\%2C8\%2C4\%2C122 [Consulta: 10/04/2021]

- Ampparito (2021) @Ampparito [Perfil de Instagram]. Instagram. Disponible en: https://www.instagram.com/ ampparito/ [Consulta: 12/04/2021]

- Borondo, G. (2021) @gonzaloborondo [Perfil de Instagram]. Instagram. Disponible en: https://www.instagram.com/ gonzaloborondo/ [Consulta: 12/04/2021]

- Clément, G. (2007) Manifiesto del Tercer paisaje. Barcelona: Gustavo Gili, pp. 6-7

- Gayo, E. y Gracia, S. (2018) Arte urbano y muralismo contemporáneo, un dilema para la gestión de proyectos de conservación-restauración. En: Monográfico: Las profesiones del Patrimonio Cultural. Madrid: ACRE y GE-IIC, pp. 81-84

- Les forces du desorde (2021) @les_forces_du_desordre [Perfil de Instagram] Instagram. Disponible en: https://www. instagram.com/les_forces_du_desordre_/ [Consulta: 12/04/20 21] 